\title{
UKRYTY FRAGMENT CZARNOGÓRSKIEJ HISTORII: PRZYŁACCZENIE CZARNOGÓRY DO SERBII W 1918 ROKU
}

UWAGI WSTĘPNE

$\mathrm{O}$ koliczności przyłączenia Królestwa Czarnogóry do Królestwa Serbii w listopadzie 1918 roku nie stanowiły szczególnego obszaru zainteresowań polskich naukowców, a zasadnicza część tego wydarzenia nie została dotąd dostatecznie opisana w polskiej literaturze. Taki stan rzeczy wyniknął z ograniczonej dostępności materiałów źródłowych, a także był konsekwencją utrwalonego mitu o jednomyślnej decyzji Czarnogórców pragnących znaleźć się pod serbskim berłem Karađorđeviciów ${ }^{1}$. Żywotność tego mitu z dużą starannością pielęgnowały jugosłowiańskie władze zarówno w królewskiej, jak i socjalistycznej formie państwa. Tymczasem w okresie stopniowego procesu uniezależniania się Czarnogóry od Serbii, zapo-

Mgr Konrad Sebastian MORAWSKI jest historykiem, doktorantem na Uniwersytecie Rzeszowskim. konrad.morawski@wp.pl - • • •

Warto zwrócić uwagę na niewielki zasób polskich opracowań odnoszących się w sposób gruntowny do procesu utworzenia Królestwa SHS. Istotną wartość w tym zakresie wniosły: Jugosławia. Zarys dziejów Leszka Podhorodeckiego z 1979 roku, Historia Jugosławii Wacława Felczaka i Tadeusza Wasilewskiego z 1985 roku, a także Historia Słowian południowych i zachodnich Jerzego Skowronka, Mieczysława Tantego i Tadeusza Wasilewskiego z 1988 roku. Należy również wspomnieć o bogatym dorobku Henryka Batowskiego, któremu nie pozostawały obce problemy jugosłowiańskie. Ważną rolę w polskiej literaturze w kontekście utworzenia Królestwa SHS spełniła wydana w 1994 roku praca Antoniego Gizy pt. Narodziny i rozpad Jugosławii, aczkolwiek autor nie rozpatrywał okoliczności przyłączenia Czarnogóry do Serbii, choć należy dodać, iż w skromnej formie wspomniał o problemach wewnętrznych w Królestwie SHS, wynikających m.in. z podziałów politycznych w Czarnogórze. Osiem lat później w opracowaniu Antoniego Gizy i Janusza Gmitruka pt. Tajne raporty z Jugosławii problem czarnogórski nie został rozwinięty; oszczędny w słowach na ten temat był również Wiesław Walkiewicz w dziele zatytułowanym Jugosławia. Wielu polskich badaczy problematyki jugosłowiańskiej, takich jak Irena Stawowy-Kawka, Piotr Eberhardt, Marek Waldenberg, Michał Jerzy Zacharias i inni, skupiło się przede wszystkim na zagadnieniach związanych z drugą formą ustrojową państwa jugosłowiańskiego lub na problemach bezpośrednio niezwiązanych z politycznym procesem powstania Królestwa SHS. W pracach tych znakomitych naukowców problem czarnogórski nie stanowił większego zainteresowania, a również część współczesnych zachodnioeuropejskich badaczy konsekwentnie pomijała ten temat. Warto tu wspomnieć dwukrotnie wznawiane, wciąż niewystarczające opracowanie Leslie Bensona pt. Yugoslavia: A Concise History, wydaną w Londynie pracę Dejana Djokicia pt. Elusive Compromise: A History of Interwar Yugoslavia oraz artykuł Stevana K. Pavlowitcha zatytułowany Serbia, Montenegro and Yugoslavia, który wszedł w skład pracy zbiorowej pod redakcją Dejana Djokicia pt. Yugoslavism. Histories of a Failed Idea 1918-1992. 
czątkowanego jeszcze w realiach Federalnej Republiki Jugosławii, grupa czarnogórskich i czarnogórsko-bośniackich naukowców zmierzyła się z wspominanymi wcześniej okolicznościami. Rezultaty ich badań podały w wątpliwość rzeczoną jednomyślność, a także wymogły redefinicję ustalonych wyobrażeń wobec wydarzeń z listopada 1918 roku.

Problemy powstałe w okresie przyłączeniowym Czarnogóry do Serbii zasygnalizował już w 1981 roku czarnogórski historyk Dimitrije Vujović, aczkolwiek jego wydana niedługo po śmierci Josipa Broza Tito praca pt. Crnogorski federalisti 1919-1929 ze względu na brak zachodnioeuropejskiego tłumaczenia oraz ograniczony nakład nie uzyskała w tamtym okresie szerokiej recepcji. Problemy zasygnalizowane przez Vujovicia dosyć ostrożnie podjął chorwacki naukowiec Ivo Banac, który w 1984 roku w swoim najgłośniejszym dziele pt. The National Question in Yugoslavia: Origins, History, Politics zwrócił uwage na antyserbskie nastroje w królewskiej Czarnogórze.

Niezwykle ważną pracą odnoszącą się do czarnogórskiego oporu wobec przyłączenia państwa do Serbii było wydane w 1996 roku dzieło Šerbo Rastodera zatytułowane Skrivana strana istorije: Crnogorska buna i odmetniči pokret 1918-1929, aczkolwiek również i w tym przypadku brak tłumaczenia oraz ograniczony zasięg publikacji, wydanej w kilkunastotysięcznym mieście Bar, nie dorównat jej wielkiemu znaczeniu historiograficznemu². Niemniej już sześć lat później ten czarnogórsko-bośniacki naukowiec opublikował na łamach międzynarodowego wydawnictwa pod redakcją Floriana Biebera anglojęzyczny artykut pt. A Short Review of the History of Montenegro, w którym szczegółowo odniósł się do ukrywanych przez lata przesłanek włączenia Czarnogóry do Serbiii ${ }^{3}$. Badania tego autora zostały dodatkowo utrwalone w styczniu 2006 roku, a więc w klimacie niepodległościowym dla Czarnogórców, kiedy Rastoder wraz z innym badaczem czarnogórskich dziejów, Živko Andrijaševiciem, opublikował anglojęzyczną historię Czarnogóry pod tytutem History of Montenegro: from Ancient Times to 2003.

$\mathrm{Na}$ łamach wspominanego wydawnictwa pod redakcją Floriana Biebera artykuł zatytułowany Who are Montenegrins? Statehood, identity, and civic society opublikowat również Srđa Pavlović. Jednak najistotniejsze dzieło tego autora, a w kategorii stosowanych pojęć wręcz przełomowe, zostało wydane w 2008 roku. Już sam tytuł opracowania, Balkan Anschluss: The Annexation of Montenegro and the Creation of the Common South Slavic State, wskazał na zasugerowany przez Pavlovicia charakter przyłączenia Czarnogóry do Serbii. W tymże opracowaniu czarnogórski historyk, eseista i tłumacz literatury w drobiazgowy sposób opisał kolejne etapy kształtowania się sytuacji politycznej czarnogórskiego Królestwa w okresie pierwszej wojny światowej, a także wydarzenia bezpośrednio poprzedzające utworzenie Królestwa SHS oraz zrywy powstańcze Czarnogórców już w realiach serbsko-chorwacko-słoweńskich.

Pomimo że w opracowaniach Šerbo Rastodera i Srđy Pavlovicia wystąpiło kilka różnic o charakterze semantycznym w kontekście samej natury włączenia Czarnogóry do Serbii, to konkluzje obu autorów sprowadzały się do jednoznacznych wniosków. Czarnogóra nie oddała niepodległości, tylko ją Królestwu odebrano, a wszelkie próby sprzeciwu wobec serbskich planów kończyły się fatalnymi w skutkach konsekwencjami dla ich autorów. Tym samym, mając na uwadze ważkość tego tematu oraz jego niedostateczne opra-

2 Wymownie brzmiące, czteroczęściowe wydawnictwo, w autorskim tłumaczeniu "Ukryta strona historii: Czarnogórski bunt i ruchy rebelianckie 1918-1929", zawierało 1759 oryginalnych dokumentów świadczących o potrzebie redefinicji historii Czarnogóry w kontekście czarnogórsko-serbskiego połączenia i jego konsekwencji.

3 Zob. Š. Rastoder, A Short Review of the History of Montenegro, [w:] Montenegro in Transition. Problems of Identity and Statehood, red. F. Bieber, Baden-Baden 2003, s. 107-137. 
cowanie w polskiej literaturze, należy podjąć się wstępnego zarysu analizy. W artykule poza wspomnianymi opracowaniami oraz zebranym materiałem źródłowym zostały nadto wykorzystane materiały po stronie polskiej z okresu istnienia Królestwa Polskiego oraz II Rzeczypospolitej, w których wszelkie nawiązania do problemu czarnogórsko-serbskiego dodały dodatkowego waloru tejże pracy wobec oczekiwań polskiego czytelnika. Autor zwraca uwage, iż w wszelkie daty zawarte w artykule zostały podane na podstawie reguł kalendarza gregoriańskiego, zaś wielu czarnogórskich i czarnogórsko-bośniackich historyków opierało się na kalendarzu juliańskim.

\section{OKOLICZNOŚCI PRZYŁACZENIA CZARNOGÓRY DO SERBII}

Redaktorzy "Monitora Polskiego" w wydaniu z 5 listopada 1918 roku rozważali różne warianty niejasnej przyszłości Królestwa Czarnogóry. Znamienną wartość w tym kontekście wyraziły słowa byłego Ministra Sprawiedliwości i Spraw Wewnętrznych w czarnogórskim królewskim rządzie Janko Spasojevicia“, który na łamach francuskojęzycznej "Gazette de Lausanne" wskazał na polityczny kurs obrany przez Czarnogórców:

„Wojenne cele Czarnogóry są jasne i określone. Walczyliśmy w imię zjednoczenia Czarnogórza z Serbją, a wogóle dążymy do zjednoczenia narodu serbskiego z pobratymcami Chorwatami i Serbami i utworzenia niepodzielnego państwa demokratycznego. W tym kierunku wypowiedział się parlament czarnogórski".

Tenże polityk bez skrupułów krytykował również samego monarchę czarnogórskiego oraz wypowiadał się z nieco populistycznym zacięciem o przyszłości Czarnogóry:

„(...) polityka króla nie była wykładnikiem dążeń narodu i że na przyszłość dla dobra Czarnogóry i narodu serbskiego kraj ten należy wcielić do Serbji. Królestwo czarnogórskie winno przestać istnieć" 5 .

Pewność siebie Spasojevicia w głoszeniu poglądów, które narażały go na gniew ze strony przebywającego w Paryżu króla Mikołaja I Mirkovicia Petrovicia-Njegoša nie była bezzasadna. Wszakże w listopadzie 1918 roku tego onegdaj zaufanego polityka na królewskim dworze należało postrzegać jako jednego z czołowych działaczy czarnogórskich na emigracji, który wyrażał zdecydowane proserbskie zapatrywania na przyszłość swojego kraju.

Oto bowiem 4 marca 1917 roku Spasojević wraz z innymi byłymi ministrami w czarnogórskim królewskim rządzie utworzył w Paryżu Czarnogórski Komitet ds. Zjednoczenia, którego priorytety były zogniskowane wokół szybkiego i bezwarunkowego przyłączenia do Serbii, często nazywanego bezrefleksyjnie zjednoczeniem. Natomiast z dniem 25 października 1918 roku, a więc w okresie rychłego zakończenia pierwszej wojny światowej, została ustanowiona Centralna Egzekutywa Komitetu ds. Zjednoczenia Serbii z Czarnogórą, w skład której poza Spasojeviciem weszli: serbski delegat Svetozar Tomić (później wybrany na przewodniczącego Egzekutywy), były minister sprawiedliwości oraz oświa-

4 W cytowanym numerze "Monitora Polskiego" zostało przytoczone nazwisko Giorgja Sperojevica, ale ponad wszelką wątpliwość chodziło o wielkiego zwolennika bezwarunkowego przyłączenia Czarnogóry do Serbii, Janko Spasojevicia, który podwójna funkcje ministerialna sprawował w okresie od 29 kwietnia 1916 do 4 stycznia 1917 roku, a następnie wyemigrował do Francji. Przyczyn błędu nie ustaliłem. Zob. S. Pavlović, Balkan Anschluss: The Annexation of Montenegro and the Creation of the Common South Slavic State, Purdue University 2008, s. 92, 147-149; St. Stanojević, Narodna enciklopedija srpsko-hrvatsko-slovenačka, t. IV, Beograd 1929, s. 911-917.

5 Pisownia oryginalna. Cyt. za „Monitor Polski”, 1918, nr 195, „Kronika polityczno-społeczna”. 
ty i spraw kościelnych w czarnogórskim królewskim rządzie Milosav R. Raičević, a także związany ze środowiskiem politycznym Czarnogórców w Salonikach Petar Kosović. Zadania Egzekutywy wiązały się z opracowaniem trybu powołania Wielkiego Zgromadzenia Narodowego, które miało zadecydować o przyłączeniu Czarnogóry do Serbii 6 .

Ostrości w konflikcie pomiędzy królem Mikołajem I a częścią jego byłych ministrów dodawał fakt, że polityczna rozgrywka pomiędzy nimi miała miejsce w Paryżu, a więc w dalekiej odległości od rodzinnych stron, o które toczył się spór. Monarcha czarnogórski pomimo słabnącego autorytetu wciąż dysponował silnym zapleczem politycznym i wojskowym. Natomiast ciągłość organizacyjną komitetowi gwarantowało wsparcie serbskie, którego znaczenie przewyższało liczne próby podejmowane przez królewskich agentów, mające na celu skompromitowanie Spasojevicia oraz reszty proserbsko zorientowanych Czarnogórców. W sporze jednak zapomniano o społeczeństwie czarnogórskim, które zostało uprzedmiotowione w tej pozbawionej kompromisów rywalizacji politycznej. Wewnętrzny konflikt Czarnogórców pomiędzy obozem królewskim i proserbskim dobitnie świadczył o głębokim podziale, jaki wykształcił się w tym narodzie w trakcie pierwszej wojny światowej. Samej genezy konfliktu należy doszukiwać się w kontekście, uwarunkowanej niepowodzeniami wojennymi i zagrożeniem państwa ze strony austro-węgierskiej, ucieczki z kraju monarchy ${ }^{7}$, która uruchomiła zdecydowaną działalność Serbów obliczoną na jego detronizację i włączenie Czarnogóry do swojego państwa. Niemniej stopniowa słabnąca pozycja polityczna króla bynajmniej nie przeszkadzała mu w utrzymywaniu aspiracji względem Czarnogóry, bo zaledwie dwa dni po wypowiedzi Spasojevicia za pośrednictwem amerykańskiej agencji prasowej wyraził on nadzieję "stania się częścią nowego Państwa Jugosławia"8. Ponadto czarnogórski monarcha, nie zważając na nastroje panujące w proserbskim środowisku politycznym, prowadził samodzielną politykę względem miejsca dla Czarnogóry w powojennym porządku międzynarodowym.

Działalność Mikołaja I wyrażała się w korespondencji z prezydentem Stanów Zjednoczonych Ameryki Woodrowem Wilsonem, którego władca Czarnogóry zapewniał w listach o szczęściu, jakie panuje $w$ Jugosławii ${ }^{9}$ z powodu zjednoczenia, wychwalał zalety swojego narodu, a także pisał o zdradzie, jaką w trakcie wojny przeżyła cała Czarnogóra. Ponadto, czarnogórski monarcha wyraził nadzieję na nawiązanie stosunków dyplomatycznych z USA, ukierunkowanych przede wszystkim na powrót do kraju Czarnogórców, którzy wyemigrowali za ocean w okresie pierwszej wojny światowej. Król Mikołaj I w tym

\section{- • • •}

6 Obok Spasojevicia wśród głównych organizatorów komitetu należy wyróżnić byłego dwukrotnego premiera, dwukrotnego ministra spraw zagranicznych, trzykrotnego ministra finansów i budowy oraz pełniącego obowiązki ministra wojny, Andrija Radovicia, byłego trzykrotnego ministra oświaty i spraw kościelnych oraz pełniącego obowiązki ministra sprawiedliwości Pero Vučkovicia oraz byłych ministrów wojny Ivo Đurovicia i Danilo Gatalo. Część tych urzędów była sprawowana jeszcze w okresie istnienia Księstwa Czarnogóry. Zob. S. Pavlović, op. cit., s. 147-149; St. Stanojević, op. cit., s. 911-917.

7 Król Mikołaj I zadecydował o przystąpieniu Czarnogóry do wojny 24 lipca 1914 roku. Tego dnia zaoferował bezwarunkowe poparcie dla Królestwa Serbii, a także jednocześnie wypowiedział wojnę Austro-Węgrom. Jego decyzja, wbrew niechęci do Karađorđeviciów, była obliczona na szansę poszerzenia terytoriów Czarnogóry. Wszakże czarnogórskie wsparcie dla Serbii już podczas wojen bałkańskich w latach 1912-1913 umożliwiło znaczący rozwój terytorialny państwa. Jednak taki schemat nie powtórzył się podczas pierwszej wojny światowej. W wyniku zapoczątkowanej jesienią 1915 roku wielkiej ofensywy austro-węgierskiej Królestwo Czarnogóry już w styczniu następnego roku znalazło się pod okupacją Cesarsko-Królewskiej Monarchii. Bezwarunkowa kapitulacja Czarnogóry została podpisana 25 stycznia 1916 roku. Wcześniej z kraju uciekli: 17 stycznia głównodowodzący Naczelnego Dowództwa Czarnogóry serbski pułkownik Petar Pešić oraz 19 stycznia król Mikołaj I, który po bezskutecznej próbie uzyskania azylu w Rosji udał się do Italii, a następnie do Francji.

8 Montenegro Puts Hope in President Wilson. King Nicholas Says Nation Looks to Him for a Safe and Independent Future, „The New York Times”, November 1918.

9 Król Mikołaj I w odniesieniu do zjednoczonego państwa Słowian południowych nie zwykł używać innej nazwy niż Jugosławia. 
okresie w sensie formalnoprawnym pozostawał jedynym oficjalnym władcą Czarnogóry, ale treść jego wystąpień i korespondencji świadczyły o stopniowym zatracaniu rzeczywistości politycznej, w której funkcjonował. Potwierdziła to zaadresowana do narodu czarnogórskiego listopadowa odezwa w brzmieniu:

„Bracia! Z najżywszym i najbardziej radosnym entuzjazmem, przy oczywistej aprobacie mojego wiernego narodu, uroczyście oświadczam, że moja umiłowana Czarnogóra powinna stać się częścią składową Jugosławii i wejść w skład jugosłowiańskiej wspólnoty szczerze i uczciwie tak, jak o to walczyła i za to cierpiała. Wyobrażam sobie, że zjednoczymy się jak bracia w skonfederowanej Jugosławii, w której każde (państwo?) zachowa swoje prawa, instytucje, religię i obyczaje, w którym nikt nie będzie śmiał pretendować do supremacji, ale w którym wszyscy będą równi"10.

Pomimo braku pewności, co do struktury i formy zjednoczonego państwa lub federacji państw, Mikołaj I z pewnością liczył na triumfalny powrót do zjednoczonego południowosłowiańskiego Królestwa jako współgospodarz władzy. Wśród jego wyobrażeń znalazły się tłumy Czarnogórców wiwatujących na jego cześć i gotowych służyć pod jego rządami.

Tymczasem swój plan wobec Czarnogóry konsekwentnie wdrażali Serbowie, którzy nie bez satysfakcji realizowali założenia Ruchu na Rzecz Zjednoczenia, zapoczątkowanego już w 1916 roku przez premiera w królewskim rządzie Karađorđeviciów, Nikolę Pašicia. Działalność ruchu była oparta na dwóch podstawowych założeniach: bezwarunkowego przyłączenia Czarnogóry do Serbii oraz detronizacji czarnogórskiego monarchy. Zdaniem Dimitrije Vujovicia, koncepcja Pašicia w kontekście włączenia Czarnogóry do Królestwa Karađorđeviciów nie zakładała powstania zjednoczonego państwa jugosłowiańskiego, ale wstępną fazę utworzenia Wielkiej Serbii ${ }^{11}$, co wobec rosnącego od 1916 roku znaczenia Królestwa Serbii nie było bezzasadne i umożliwiało serbskim politykom z królewskiego rządu Karađorđeviciów dyktowanie warunków w procesie nazywanym zjednoczeniowym. Tym bardziej że wojska serbskie przy wsparciu militarnym państw Ententy ostatecznie 11 listopada 1918 roku oswobodziły Czarnogóre spod austro-węgierskiej okupacji. Bliska współpraca Serbii z państwami Ententy wiązała się jeszcze z zablokowaniem możliwości powrotu do kraju czarnogórskiego monarchy oraz jego stronników, a także umożliwiła utrzymywanie wojsk na terytorium Czarnogóry przez kolejne miesiące ${ }^{12}$.

Taki stan rzeczy był niezwykle korzystny dla Serbów w kontekście przeprowadzenia pozorowanego demokratycznego procesu włączenia Czarnogóry do serbskiego Królestwa. Wszakże nieformalnie organem stanowiącym władzę na terytorium czarnogórskim została w połowie listopada Centralna Egzekutywa Komitetu ds. Zjednoczenia Serbii z Czarnogórą, która przy pogwałceniu wszelkich procedur prawnych przewidzianych w Królestwie Czarnogóry, w tym przede wszystkim Konstytucji z 1905 roku, rozpoczęła działania mające na celu powołanie Zgromadzenia Narodowego ${ }^{13}$. Reprezentację narodu czarnogórskiego miato stanowić 165 deputowanych wybranych z dwóch list wyborczych, podzielonych zgodnie z kryterium różnicującym chęć przystąpienia Czarnogóry do Serbii. Pierwszą listę utworzyli proserbscy Bjelaši (Biali) pod przewodnictwem serbskiego duchownego Gavrilo Dožicia, zaś drugą, dążący do zachowania niezależności Królestwa, Zelenaši (Zieloni) pod przewod-

\section{-.....}

10 Tłumaczenie własne. Montenegro Puts Hope in President Wilson..., op. cit.

11 D. Vujović, Crnogorski federalisti 1919-1929, Titograd 1981, s. 13.

12 Wojska angielskie i amerykańskie opuściły Czarnogórę w kwietniu 1919 roku, francuskie w marcu 1920 roku, a włoskie w czerwcu 1920 roku. W kraju pozostały wojska serbskie, które zostały wkrótce przemianowane na Królewską Armii Jugosławii.

13 W literaturze czarnogórskiej przyjęło się również określenie Zgromadzenie Podgoricy, któremu nadano wyraźny wydźwięk pejoratywny. Wszakże stolicą Czarnogóry oraz ośrodkiem książęcej i królewskiej władzy w latach 1878-1918 była Cetynia, ale Serbowie i proserbscy Czarnogórcy zorganizowali siedzibę Zgromadzenia w Podgoricy, co dodatkowo podkreślało chęć zerwania z atrybutami władzy Mikołaja I. 
nictwem czarnogórskiego dyrektora Szkoły Klasycznej w Cetyni, profesora Špiro Tomanovicia. Pomijając fakt, że duża część królewskiego środowiska politycznego przebywała na emigracji i nie miała możliwości powrotu do kraju, uzasadnione wątpliwości budził również system wyborów, w którym nie zostały ustalone listy wyborców, co rzecz jasna stworzyto pole do wielkich nadużyć ze strony obozu proserbskiego. Dimitrije Vujvoić udowodnit, że zwolennicy czarnogórsko-serbskiego połączenia wybrali delegatów już podczas prywatnych posiedzeń, a same wybory miały tylko upozorować legalność włączenia Czarnogóry do Serbii ${ }^{14}$. W istocie wybory przeprowadzone 19 listopada 1918 roku z ogromną przewagą wygrali Bjelaši, którzy w szybkim trybie przystąpili do działań przyłączeniowych.

Na mocy „jednomyślnej” decyzji podjętej 26 listopada Zgromadzenie Narodowe przypieczętowało włączenie Czarnogóry do Serbii. W treści decyzji zapadły trzy główne postanowienia: o detronizacji Mikołaja I Mirkovicia Petrovicia-Njegoša i jego dynastii, o bezwarunkowym zjednoczeniu Czarnogóry z Serbią w ramach jednego państwa pod berłem Karađorđeviciów, a także o zgodzie na kontynuację procesu zjednoczeniowego w ramach wspólnej „ojczyzny" Serbów, Chorwatów i Słoweńców ${ }^{15}$. Tę, podjętą w nielegalnym trybie, decyzję przekazano w następnych dniach czarnogórskiemu królowi, rządowi serbskiemu i innym zaprzyjaźnionym rządom ze środowiska międzynarodowego. Pomimo protestów zdetronizowanego monarchy przyłączenie Czarnogóry do Serbii stało się faktem, zatwierdzonym przez uczestników środowiska międzynarodowego. Na mocy jednej decyzji naród czarnogórski stał się ludem serbskim, który wkrótce miał też wejść w skład zjednoczonego Królestwa południowosłowiańskiego ${ }^{16}$

Interesujące, że polski rząd Moraczewskiego już 25 listopada otrzymał z Belgradu telegram o podjętych postanowieniach połączenia Państwa SHS z Serbią i Czarnogórą pod berłem Karađorđeviciów ${ }^{17}$. Treść telegramu świadczyła o jednomyślnym ośrodku decyzyjnym Serbii i Czarnogóry, aczkolwiek samo wymienienie w telegramie nazwy Czarnogóra sugerowało ostrożność Serbów w jeszcze nieukończonym procesie przyłączeniowym tego państwa do Serbii, co nastąpiło dopiero następnego dnia ${ }^{18}$. W grudniowych polskojugosłowiańskich relacjach nazwa Czarnogóry nie była już wymieniana, a wyjątkowo gorzkim w tej materii wydarzeniem było wystosowanie 13 grudnia odezwy polskich pisarzy do pisarzy czeskich, słowackich, słoweńskich, serbskich i chorwackich. W donośnie brzmiących sformułowaniach polscy pisarze zaakcentowali solidarność wobec uciskanych naro-

- - - •

14 D. Vujović, op. cit., s. 14

15 Moim zdaniem określenie „ojczyzna” to propozycja wytrawnego gracza dyplomatycznego, jakim był Nikola Pašić. Określenie użyte w kontekście czarnogórsko-serbskiego połączenia ma zdecydowanie populistyczny i nieosadzony w rzeczywistości politycznej wydźwięk, aczkolwiek taka formuła znajduje uzasadnienie w kontekście zjednoczenia Królestwa Serbii i Państwa SHS, a także w perspektywie międzynarodowej legitymizacji zjednoczonego Królestwa południowosłowiańskiego. Zob. Š. Rastoder, A Short Review..., s. 130.

16 Naród czarnogórski w oficjalnych statystykach demograficznych został po raz pierwszy uwzględniony w 1948 roku, a więc już w realiach socjalistycznej Jugosławii. Dane w tym zakresie z wcześniejszego okresu nie uwzględniały odrębności narodowej Czarnogórców, którzy byli traktowani jako Serbowie. Taki stan rzeczy potwierdzają badania Aleksandra Rakovicia oraz Piotra Eberhardta. Warto dodać, że polski uczony w swojej głośnej pracy z 2005 roku pt. Przemiany demograficzno-etniczne na obszarze Jugostawii w XX wieku w cześci statystycznej badań powołał się na niekwestionowany autorytet w dziedzinie problematyki etnicznej i narodowościowej na Bałkanach, profesora Károly Kocsisa z Węgierskiej Akademii Nauk. Należy jednak, za profesorem Eberhardtem, zauważyć, że nawet pomimo nieuwzględniania Czarnogórców w oficjalnych statystykach demograficznych, w tym okresie istniały już przesłanki wpływające na poczucie czarnogórskiej tożsamości narodowej, takie jak własna historia, prawo, religia, niepodległość, a także kultura, w której nie bez znaczenia były poetyckie inklinacje Mikołaja I. Zresztą tenże monarcha w okresie istnienia Królestwa Czarnogóry utrwalił w swoich wypowiedziach istnienie par excellence narodu czarnogórskiego, choćby w deklaracji przystąpienia do pierwszej wojny światowej. Zob. P. Eberhardt, Przemiany demograficzno-etniczne na obszarze Jugosławii w XX wieku, Lublin 2005, s. 103-108; A. Raković, Nacionalni identitet u Crnoj Gori, „Pravda”, Februar 2004, s. 12.

17 Oficjalny początek istnienia Królestwa SHS datuje się na 1 grudnia 1918 roku.

18 "Monitor Polski”, 1918, nr 218, „Kronika polityczno-społeczna”. 
dów słowiańskich oraz przekazali pełne patosu pozdrowienia, będące niejako zapowiedzią wolności opartej na wzajemnej przyjaźni. Wymieniono tu poszczególne narody wchodzące w skład Królestwa SHS, ale pominięto Bośniaków, Czarnogórców oraz Macedończyków¹9.

\section{ZA SPRAWIEDLIWOŚĆ, HONOR I WOLNOŚĆ CZARNOGÓRY!}

Niemal miesiąc po wydarzeniach w Podgoricy zdetronizowany król Mikołaj I wypowiedział się dla amerykańskiej agencji prasowej w słowach, które świadczyły o dużej trosce wobec roli Czarnogóry w „Jugosłowiańskiej Konfederacji”. Król we właściwym sobie doniosłym tonie rozprawiał o niezwykłej dzielności i odwadze Czarnogórców, którzy przez pięć stuleci bronili przed opresjami Muzułmanów tak swój interes, jak i interes krajów sąsiadujących, a także wyrazili solidarność z Serbami podczas pierwszej wojny światowej. W tej reminesencji czarnogórskich dziejów zdetronizowany władca wyraził również dyplomatycznie brzmiącą uwagę o konieczności zabezpieczenia autonomii i niezależności Czarnogóry w państwie jugosłowiańskim²0. Właśnie czynnik dyplomatyczny, w porównaniu do wypowiedzi króla z przełomu listopada i grudnia, nabierał coraz większego znaczenia. Wszakże już w tym okresie pomiędzy nim a prezydentem USA Woodrowem Wilsonem toczyła się gra dyplomatyczna, której stawką było przeprowadzenie legalnych wyborów w Czarnogórze, mających raz jeszcze zdecydować o przyszłości tego państwa. Król zdawał sobie sprawę, że jedyną możliwością odbudowy jego władzy było wzbudzenie zainteresowania środowiska międzynarodowego sprawą czarnogórską, aczkolwiek jednocześnie popierał działalność przeciwników czarnogórsko-serbskiego połączenia, którzy już na początku grudnia rozpoczęli przygotowania do powstańczego zrywu. Być może gra dyplomatyczną, w którą uwikłał się król była następstwem ogólnoświatowych spekulacji, iż w paryskiej konferencji pokojowej po stronie jugosłowiańskiej przewiduje się reprezentację w osobie Ante Trumbicia, a więc wielkiego zwolennika procesu zjednoczeniowego narodów południowosłowiańskich. Taki stan rzeczy świadczył o legitymizacji Królestwa SHS w środowisku międzynarodowym, a zatem o odrzuceniu jakichkolwiek roszczeń po stronie królewskiego obozu Czarnogóry²1.

W ten sposób w imieniu Mikołaja I oraz z jego przyzwoleniem w pierwszych dniach grudnia pod szyldem Zelenaši zaczęli organizować się przeciwnicy czarnogórsko-serbskiego połączenia, którzy dążyli do wywołania powstańczego zrywu. Ich politycznym liderem został prominentny polityk i wielokrotny minister w czarnogórskim królewskim rządzie, Jovan Simonov Plamenac. Grupa niezadowolonych wywodziła się ze struktur politycznych

\section{-.....}

19 O ile struktura narodowościowa Bośni i Hercegowiny obejmowała współmiernie narody Chorwatów, Muzułmanów i Serbów, o tyle trudno przypuszczać, aby polscy pisarze nie byli wyposażeni choćby w symptomy świadomości odrębności Czarnogórców i Macedończyków. Warto tu wymienić przede wszystkim działalność Petroviciów-Njegošów po stronie Czarnogóry oraz przedstawicieli tzw. Nowej Macedońskiej Literatury po stronie Macedonii, którzy na przełomie XIX i XX wieku w różnych wymiarach wyposażali swoje narody W atrybuty tożsamości narodowej i poczucie odrębności. Zob. „Monitor Polski”, 1918, nr 228, „Kronika polityczno-społeczna".

20 King Nicholas Will Meet Wilson, "The New York Times”, December 1918.

21 Czarnogórcy otrzymali możliwość wystania jednego delegata na styczniowe obrady konferencyjne, aczkolwiek nie została ustalona procedura jego wyboru. Przebywający na obradach delegaci Królestwa SHS uznali za bezpodstawną obecność pustego krzesła z napisem Czarnogóra, sytuacja w tym kraju bowiem została już uregulowana. Tak czy inaczej podczas marcowych obrad konferencyjnych czarnogórski rząd na emigracji wymógł wyłożenie swoich racji, które jednak nie spotkały się ze zrozumieniem Rady Najwyższej Konferencji. Zob. 21 listopada, notatka przedstawicielstwa w Bernie dla MSZ w sprawie konferencji pokojowej, [w:] Polskie dokumenty dyplomatyczne 1918 listopad-grudzień, red. S. Dębski, Warszawa 2010, s. 60-61. 
i inteligenckich, które ponadto prowadziły akcje pozyskiwania zwolenników z niższych warstw czarnogórskiego społeczeństwa. Stałe wsparcie przeciwnikom przyłączenia zapewniali stopniowo powracający z obozów jenieckich, wierni zdetronizowanemu monarsze, oficerowie czarnogórskiej królewskiej armii. Na ich czele należy wyróżnić przede wszystkim bohatera wojen bałkańskich i pierwszej wojny światowej kapitana Krsto Zrnova Popovicia. W sumie po stronie organizującej zryw powstańczy znalazło się około 4000 czarnogórskich polityków, inteligentów, wojskowych i ludzi z niższych warstw społecznych. Swój interes w powodzeniu powstania widział też królewski rząd Włoch, którego wsparcie polegało na pomocy w utworzeniu i wyposażeniu czarnogórskiej armii na emigracji22.

Powstanie bożonarodzeniowe (w czarnogórskim oryginale Božićna Pobuna) wybuchło 7 stycznia 1919 roku, a więc w święta Bożego Narodzenia w Cerkwi prawosławnej. Przyświecało mu hasło: „Za sprawiedliwość, honor i wolność Czarnogóry!”, aczkolwiek zapałowi powstańców nie dorównywała sama organizacja tego zrywu. Zelenaši dysponowali bardzo ograniczonymi zapleczem militarnym, a przecieki o organizacji powstania kilka dni przed jego rozpoczęciem dotarły do sztabu Armii Serbskiej. Zresztą na ich podstawie zdołano aresztować m.in. jednego z politycznych przywódców powstania, byłego ministra wojny i spraw wewnętrznych w czarnogórskim królewskim rządzie Marko Dukanovicia ${ }^{23}$. W ten sposób naprzeciw 4000 słabo przygotowanych Czarnogórców stanęło około 10000 serbskich i czarnogórskich wojskowych pod politycznym przywództwem Czarnogórca Marko Dakovicia. Walki, które miały miejsce w pobliżu Cetyni, zakończyły się klęską powstańców, ale wydarzenia tego dnia zapoczątkowały partyzancką działalność Zelenaši, którzy do 1924 roku organizowali spontaniczne zrywy powstańcze ${ }^{24}$.

Od tej działalności jeszcze w styczniu 1919 roku odciął się Mikołaj I, któremu prezydent Wilson oficjalnie zagwarantował iż w Czarnogórze wkrótce zostaną przeprowadzone wolne wybory będące podstawą decyzji o przyszłości kraju. Tym samym czarnogórski monarcha, skuszony wizją powrotu na tron, wydał oficjalne oświadczenie, w którym wyraził prośbę o zaprzestanie oporu powstańczego. Ponadto, król 17 lutego zorganizował czarnogórski rząd na emigracji, ze strukturą identyczną do tej w okresie jego panowania w Księstwie oraz Królestwie Czarnogóry. Premierem, ministrem spraw zewnętrznych i ministrem spraw wewnętrznych został ściągnięty do Paryża po nieudanym powstaniu bożonarodzeniowym Jovan Simonov Plamenac, zaś pozostałe teki otrzymali: Milutin Vučinić (Ministerstwo Wojny), Pero Šoć (Ministerstwo Sprawiedliwości oraz Ministerstwo Oświaty i Spraw Kościelnych), Milo M. Vujović (Ministerstwo Finansów i Budowy) ${ }^{25}$. Obietnica prezydenta Wilsona nigdy nie została spełniona, a czarnogórski rząd na emigracji zakończył oficjalnie urzędowanie 1 marca 1921 roku, wraz ze śmiercią zdetronizowanego króla. Tymczasem nie ustawały liczne zrywy powstańcze. Zdaniem Šerbo Rastodera, grupa powstańców organizowała się w czarnogórskich lasach, a najcięższe walki, które stoczyła, odbyły się na przełomie 1919 i 1920 roku. W kolejnych latach kontynuowano spontaniczne akcje powstańcze, aczkolwiek w wyniku ponoszonych strat oraz utraty włoskiego wsparcia uległy one znaczącemu ograniczeniu ${ }^{26}$.

22 Królestwo Włoch wyrażało aspiracje względem części chorwackich i słoweńskich terytoriów Królestwa SHS, a pomoc udzielona powstańcom czarnogórskim była wyrachowaną polityczną działalnością, która pomimo obecności włoskich wojsk w Czarnogórze nie obejmowała bezpośrednich działań w ramach powstańczych zrywów. Po podpisaniu włosko-jugosłowiańskiego porozumienia w listopadzie 1920 roku pomoc dla powstańców ustała, a czarnogórska armia na emigracji została rozbrojona.

23 Strona internetowa The Montenegrin Association of America, http://www.montenegro.org, "Christmas Uprising 1919" [dalej: SI TMAA 1919], inf. z 25.06.2012 r.

24 Š. Rastoder, A Short Review..., s. 130-131.

25 D. Vujović, op. cit., s. 14

26 S. Rastoder, A Short Review..., s. 132. 
Losami czarnogórskich powstańców krótkotrwale próbowała kierować królowa Milena Vukotić, aczkolwiek jej polityczne znaczenie było niewielkie. Wszak po śmierci jej męża najważniejszą rolę w królewskim obozie uzyskał Jovan Simonov Plamenac, który w tle wyniszczającego Czarnogórę konfliktu na początku 1925 roku podpisał porozumienie z Nikolą Pašiciem i powrócił do kraju. To wydarzenie historycy czarnogórscy oficjalnie łączą z zakończeniem zrywów powstańczych, aczkolwiek część z nich dodaje, że w sumie do 1929 roku dochodziło do spontanicznych walk czarnogórsko-czarnogórskich i czarnogórsko-serbskich ${ }^{27}$. Ponadto historycy spierają się co do strat związanych z działalnością powstańczą w Czarnogórze. Nie ma jednak wątpliwości, że były one niebotyczne w odniesieniu do tego małego narodu. Šerbo Rastoder stwierdzit, że około 5000 Czarnogórców zostało uwięzionych, ciężko rannych lub zamordowanych, a także zwrócił uwagę na poważne uszkodzenia dużej liczby zabudowań w kraju. Natomiast inne czarnogórskie źródła wskazują, że w ramach powstań zginęło około 3000 Czarnogórców, kolejne 3000 odniosło poważne rany, duża grupa udała się na emigrację do USA, a znacząco ucierpiało zaplecze architektoniczne państwa (szczególnie w rejonach Cetyni). Nie należy brać z powagą szacunków serbskich, zgodnie z którymi w powstaniach czarnogórskich zginęło 50 osób, kolejne 50 zostało rannych, 100 zostało uwięzionych, a setki udało się na emigrację ${ }^{28}$.

Pomimo skromnego zasobu opracowań odsłaniających kulisy przyłączenia Czarnogóry do Serbii, ewolucja terminologiczna wobec tego wydarzenia może służyć jako odzwierciedlenie poszczególnych etapów wspominanego wcześniej procesu niepodległościowego czarnogórskiej republiki na przełomie XX i XXI wieku. Wszak o ile w królewskiej Jugosławii oraz socjalistycznej Jugosławii pod rządami Tito oficjalnie głoszono mit o dobrowolnej i jednomyślnej decyzji Czarnogórców w procesie połączeniowym z Serbią, o tyle w latach osiemdziesiątych XX wieku badacze czarnogórskiej historii zaczęli ostrożnie stosować terminologię wnoszącą wątpliwości do czarnogórsko-serbskiej unifikacji, a w latach dziewięćdziesiątych XX wieku definiowali to wydarzenie jako narzucone siłą przyłączenie. W pierwszej dekadzie XXI wieku, a więc w okresie rychtego upadku ostatniej formy państwa jugosłowiańskiego i rewizji czarnogórsko-serbskiej unii, grupa historyków czarnogórskich i czarnogórsko-bośniackich zaczęła wobec wydarzeń z listopada 1918 roku używać dosadnej i terminologii, zgodnie z którą proces przyłączeniowy Czarnogóry do Serbii określono jako aneksję.

Zdaniem autora, pomimo iż okoliczności przyłączenia Czarnogóry do Serbii wiązały się z pogwałceniem królewskiego czarnogórskiego prawa, nielegalnym ustanowieniem ośrodka decyzyjnego w Podgoricy oraz presją serbską, nie należy zapominać, iż w tym wydarzeniu istotną rolę odgrywali również czarnogórscy politycy, którzy dążyli do obalenia króla Mikołaja I, a jedyną szansę powodzenia swoich planów widzieli we współpracy z Serbią, która ponadto gwarantowała zabezpieczenie czarnogórskich granic pod bertem Karađorđeviciów. To również Czarnogórcy z obozu proserbskiego walczyli wespół z Armią Serbii przeciwko królewskim powstańcom, a istotę walk powstańczych krótko po ich rozpoczęciu zakwestionował sam monarcha. Srđa Pavlović, Šerbo Rastoder, Dimitrije Vujović oraz inni czarnogórscy i czarnogórsko-bośniaccy historycy słusznie stwierdzili, że naród czarnogórski poniósł druzgocące straty w kontekście przyłączenia do Serbii, a także w wyniku następstw tego wydarzenia, aczkolwiek nie wolno zapominać o podziale, jaki wykształcił się wśród Czarnogórców już w 1916 roku i bezsprzecznym udziale byłego

\section{.....}

27 Zob. Š. Rastoder, Skrivana strana istorije: Crnogorska buna i odmetniči pokret 1918-1929, Bar 1996; SI TMAA 1919, inf. z 25.06.2012 r.

28 Por. SI TMAA 1919, inf. z 25.06.2012 r.; Š. Rastoder, A Short Review..., s. 131. 
czarnogórskiego królewskiego rządu w układach z Serbią. Zatem największą ofiarą konfliktu obozu prokrólewskiego z proserbskim nie była któraś ze stron tej politycznej rywalizacji, a uprzedmiotowiony, stale poddawany bipolarnej propagandzie oraz pozbawiony możliwości głosu niezaangażowany naród czarnogórski.

UWAGI KOŃCOWE

Czarnogórsko-serbskie połączenie przetrwało wszystkie trzy formy jugosłowiańskiej państwowości, a nawet po ostatecznym upadku federacji jugosłowiańskiej pomiędzy Czarnogórą i Serbią zachował się związek unijny. Jednak niemal 88 lat po utracie niepodległości przez Czarnogórę historia zatoczyła koło, bowiem 3 czerwca 2006 roku parlament w Podgoricy proklamował niepodległość, czym ostatecznie uniezależnił się od Serbii. Decyzję niepodległościową 21 maja 2006 roku podjęli w referendum Czarnogórcy, którzy w liczbie nieco ponad 55\% biorących udział opowiedzieli się twierdząco w kontekście zerwania czarnogórsko-serbskiej unii ${ }^{29}$.

Należy jednak zwrócić uwagę, że już od śmierci Josipa Broza Tito czarnogórskie środowiska naukowe zaczęły dochodzić genezy przyłączenia Czarnogóry do Serbii. Stopniowo ujawniane okoliczności podały w wątpliwość legalność procesu przyłączeniowego. Udowodniono, że następstwem nielegalnego wcielenia Czarnogóry do Serbii były kilkuletnie bratobójcze walki Czarnogórców z Czarnogórcami wspieranymi przez Serbów, które w konsekwencji doprowadziły do znaczących strat w ludności i zapleczu architektonicznym państwa.

Okoliczności przyłączeniowe oraz powstańcze walki Czarnogórców z obozu królewskiego zostały na przełomie XX i XXI stulecia rzetelnie opisane przez czarnogórskich i czarnogórsko-bośniackich naukowców, czym oddano hołd historycznej prawdzie, a także poległym po obu stronach inteligentom, politykom, żołnierzom oraz niezaangażowanym w konflikt zwykłym Czarnogórcom. Niemniej już w realiach niepodległej Czarnogóry pamięć o powstaniu bożonarodzeniowym i innych zrywach powstańczych z okresu 1918-1924 przeniosła się do poziomu rywalizacji głównych partii politycznych ${ }^{30}$. Zdaniem czarnogórskiego historyka Aleksandra Stamatovicia przebieg zrywów powstańczych w niepodległej Czarnogórze zdeformowano, co służy podsycaniu wrogości przeciw Serbom. W politycznym dyskursie Czarnogórców z podtrzymywanego przez jugosłowiańskie władze mitu jednomyślności o czarnogórsko-serbskim połączeniu wykształca się mit o bohaterstwie narodu wobec serbskiego oprawcy ${ }^{31}$. Rozważania wypada zatem zakończyć w sposób zaiste nienaukowy, bo posiłkując się pytaniem retorycznym: czy odtajniony fragment czarnogórskiej historii ma służyć politycznym konfliktom i utrwalaniu podziałów w Czarnogórze?

\section{$\cdots \cdots$}

29 E. Bujwid-Kurek, Państwa pojugosłowiańskie. Szkice politologiczne, Kraków 2008, s. 184.

30 Również wspótczesna historia czarnogórskiego parlamentaryzmu, począwszy od 2006 roku, różnicuje naród według dwóch głównych obozów. Swoje miejsce w tym państwie utrzymał obóz proserbski w reprezentacji Socjalistycznej Partii Ludowej Czarnogóry oraz partii serbskich, takich jak Nowa Serbska Demokracja i innych, a przeciwwagę dla niego stanowi obóz proeuropejski, posiadający zaplecze w Demokratycznej Partii Socjalistów Czarnogóry, Socjaldemokratycznej Partii Czarnogóry i innych. Należy tu jednak zauważyć, że obóz proserbski również dąży do integracji europejskiej, ale w ścisłej współpracy z Serbią.

31 Strona internetowa Radio Slobodna Evropa, http://www. slobodnaevropa.org, P. Tomović „Božićni ustanak izaziva kontroverze na 90. Godišnjicu", inf. z 26.06.2012 r. 


\section{Summary}

The circumstances accompanying the incorporation of Montenegro into Serbia in November 1918 were marked by an internal conflict in the Montenegrin nation, which, to be specific, was the conflict between King Nicholas I and his supporters on the one side and the group of pro-Serbian former ministers in Montenegrin governments on the other side. The royal camp aimed at maintaining independence of the Kingdom of Montenegro while the pro-Serbian camp's aspiration was unconditional incorporation of the country into the borders of the Kingdom of Serbia and later into the unified South Slavic Kingdom. The pro-Serbian camp tipped the scales in its favour as it organised the illegal National Assembly on the territory of Montenegro, which decided about the unification of Montenegro and Serbia and the dethronement of King Nicholas I. The consequences of this state of affairs led to a significant number of uprisings of the Montenegrins allied with the royal camp. Out of these, the Christmas Uprising gained a rank of a symbol. Montenegrin-Montenegrin and Montenegrin-Serbian fights involved considerable losses on the part of the people of Montenegro and the country's architectural wealth, yet they solidified the national awareness of the Montenegrins, and the cult of this awareness made it possible to regain independence after 88 years of strong bonds with Serbia.

Keywords: Montenegro, Serbia, independence aspirations 